\title{
Environmental aspects of media scenarios for the future ICT society
}

\author{
A qualitative study
}

\author{
Malin Picha Edwardsson \\ Media technology and Interaction design, \\ School of Computer Science and Communication, and \\ Centre for Sustainable Communications, \\ KTH Royal Institute of Technology \\ Stockholm, Sweden \\ picha@kth.se
}

\begin{abstract}
During the past 50 years, the media channels, the media consumption patterns and the entire influence of media in society have changed dramatically. Looking into the future, the pace of change is not likely to decrease. In order to prepare for the future, it is important to increase our understanding of the present, in particular with regards to the environmental aspects of media consumption. In this study, I present four future scenarios related to media consumption trends and discuss these scenarios in relation to environmental aspects in the ICT society.

I have tried to answer the following questions: What could be the characteristics of media consumption in different future scenarios? What parameters are central in future scenarios around media consumption, seen from an environmental perspective? How will changes in these parameters affect the environmental aspects of media consumption? I have limited the question to a Nordic context.

A combination of different media theories, future studies methodology and interview techniques have been used. Interviews and workshops were conducted with media and environmental experts and with consumers. The result of the interviews with consumers shows that very few consumers connect media consumption with environmental concerns. The majority of the interviewed persons considered printed media as more environmentally damaging compared to electronic media, which was considered "clean".

The environmental experts participating in this study considered the most central parameters in future scenarios of media consumption, seen from an environmental perspective, to be connected to electronic devices, travel, transportation, energy use and waste. The environmental aspects of these parameters depend not only on the amount of devices, travel, transportation, energy and waste, but also on the way the devices are produced and used, how the travel and transportation are done, what kind of energy is used, and how the waste is treated.

The amount of environmental information available in society is yet another important parameter in order to create a more environmentally sustainable future, and this is where the media could play an important role.
\end{abstract}

Index Terms-Media, scenarios, environmental parameters, consumers, ICT society

\section{INTRODUCTION AND BACKGROUND}

During the past 50 years, the media channels, the media consumption patterns and the entire influence of media in society have changed dramatically. Compared to the 1960's, we have today a vast array of TV channels, we have mobile telephones, computers in all shapes and sizes, newspapers with color print and in tabloid format, on-demand radio and television, social media, et cetera, which did not exist before. The list of changes and new technical solutions for the media business can be made very long, both when considering consumption and production of media content. The development of the media sector is also closely linked to the transformation of the ICT society as a whole [1], [2], [3], [4].

According to Bradley [5], computer technology, telecommunication technology, and media technology have converged to be defined as ICT. In this study, the term ICT society is used because it reflects the wide range of areas in which this technology plays a vital role [6].

In this study, the aim is to increase our understanding of media consumption, particularly news media consumption, in relation to different future scenarios, in particular with regards to environmental aspects. The method of using scenarios was considered suitable in this study, because of its ability to describe both a possible future situation and the path of development leading to that situation [7].

The media industry is a worldwide, multi-billion dollar industry comprising the production and distribution of content in newspapers, internet portals, magazines, radio, TV, films, books, online games and other related channels within the news and entertainment sector. During the past years, most media companies have worked hard to position themselves in relation to the on-going changes in society and to find their place in the new media landscape [cf. 4].

A large number of research reports discuss the current changes in the media landscape [1], [2], [3], [4]. According to Fuchs [8], technology shapes society in complex ways, which means that frequently there are multiple effects that can stand in contradiction to each other. One important aspect of the 
transformation of the ICT society is the process of digitalization. According to Åkesson [9], digital innovation has transformed the structure, processes and boundaries of the business landscape. A constant introduction of new digital technology, increased mobility, changing media consumption and advertising patterns as well as digital convergence are radically changing the media industry [9]. According to Hultén et al. [4] old media industries are affected by digitalization in all their aspects: production, storage, distribution, audiences' mode of reception, and patterns of use. The digitalization of content and services affect all media companies, independent of their size. It also affects the consumers, both on a short and a long term basis. Consequently, it is important to deepen our general knowledge and understanding within this area.

The environmental impact of producing media content and of consuming media in different media channels, such as printed and digital newspapers, TV and radio, have been investigated by a number of researchers [10], [11], [12], [13], [14], [15], [16], [17].

According to Kronqvist et al [12], both media consumption of printed and of online media leads to emissions of greenhouse gases. Paper production causes more emissions than any of the other processes when it comes to the printed magazine. The manufacturing of the computer is the largest source of emissions when it comes to reading a magazine online [12].

According to Arushanyan and Moberg [18], reading an online newspaper on a tablet causes significantly lower climate impact than reading on a laptop or desktop. According to Schien et al. [19], the lowest energy consumption can be reached when reading an online newspaper from a smartphone with cellular wireless connection. However, the overall impact depends on the total overall device use and the geographical location of the user, due to the electricity mix.

Yearworth et al. [20] claim that if the data volume of published content can be effectively reduced, this would result in a very large decrease in energy consumption in the data centres. They further claim that "the absence of discourse around the energy impact of data volume suggests that there has so far been little awareness in the digital media industry for this potential problem" [20, p.10].

Nygren and Wadbring [1] claim that environmental concerns will become more important for media consumers in the future. However, environmental assessments of ICT solutions present certain challenges because of the constant development of the ICT society [10]. According to Rademaker [21, p.10] the indistinct scientific facts that are available today may "cause confusion among the public with regard to how harmful for the green environment the different media in fact are."

Consequently, there is a need to increase our understanding of what parameters are important when it comes to environmental aspects of media consumption. In this study, I have chosen to use a combination of media theories, future studies methodology and interview techniques to increase our knowledge and suggest potentials for improvement.
II. DEFINITION OF SCOPE AND RESEARCH QUESTIONS In this study, I will present and discuss a number of scenarios describing the future of the media sector. However, the development of the media sector is closely linked to the transformation of the ICT society as a whole, and some of the environmental parameters mentioned in this study concern the media sector as well as other parts of the ICT society.

The scope of this research study was to:

1. Identify a number of central trends concerning change in technology and society.

2. Describe alternative scenarios, based on the identified trends. 3. Identify additional trends and environmentally related parameters, which could affect the development of the media landscape as well as the environmental aspects of media consumption.

4. Analyze how variations in these central parameters could affect the environmental aspects of media consumption.

The overall research questions are: What could be the characteristics of media consumption in different future scenarios? What parameters are central in future scenarios around media consumption, seen from an environmental perspective? How will changes in these parameters affect the environmental aspects of media consumption?

\section{THEORY AND METHODS}

In this study, a combination of different media theories, future studies methodology and interview techniques have been used. Critical media theory [8] forms the basis for my perception of media on a more general level.

One of the most important aspects of critical media studies is that the media communication process is framed by the economy, the political system and the culture. Power structures shape and are shaped by the media, and power structures condition communications processes [8]. Fuchs further claims that "the emergence of new media technologies and products is the result of capital interests and political interests. A new media technology such as the Internet is under the regime of capitalism always a sphere of capital accumulation, circulation and consumption as well as a sphere of ideology production, circulation and consumption" [8, p.108].

As Jenkins [22, p.13] expresses it: "History teaches us that old media never die. /.../What dies are simply the tools we use to access media content. /.../ Delivery technologies become obsolete and get replaced; media, on the other hand, evolve." Nygren and Wadbring further claim that old media channels usually don't disappear, but exist and evolve in parallel to the new Internet based media forms [1].

In spite of the name, the most important outcome of future studies is not knowledge and images of the future, but learning about today and what can be done now to for example reach the desired future [23]. According to Börjeson et al. [24, p.723], "one of the most basic, although contested, concepts in this field is 'scenario'. It can denote both descriptions of possible future states and descriptions of developments." Kosow and Gassner [7, p.1] describe a scenario as a "description of a possible future situation, including the path of development leading to that situation. Scenarios are not 
intended to represent a full description of the future, but rather to highlight central elements of a possible future and to draw attention to the key factors that will drive future developments."

In this study, I have mainly used the future studies techniques of workshops and scenario discussions [7], in order to explore the possible future of media. The explorative scenarios used in this study aim at answering the question What can happen? as described by Börjeson et al. [24]. Explorative scenarios of the external factors are considered to be the most appropriate choice here since the interest of the study is in exploring the consequences of alternative developments.

The process of scenario generation in this study was first carried out by a reference group consisting of three senior media experts within the respective fields of digital media, print media and media technology development, and one environmental expert within the field of life cycle assessments of media products.

At the first reference group meeting, external factors in the form of media trends were generated during a brainstorming session, partly based on Nygren and Wadbring [1]. Next, the external factors were grouped into clusters and the most influential clusters and the most uncertain clusters were discussed. At the second reference group meeting, a so-called scenario cross was created to depict the most influential dimensions, based on van der Heijden [25], and the list of media trends was discussed and further refined.

The list of media trends and the four scenarios were then presented to a number of other media experts who gave their opinions and comments, which lead to some further changes, in a Delphi-like process [7]. A Delphi-like process refers to a method where experts comment on research results and suggest improvements, which are then made and commented upon by the next round of experts et cetera in an iterative process.

A total of 11 media experts, not including the reference group, participated in the study, of which ten were based in Sweden and one in Finland. The group of media experts consisted of a mix of people from the media industry and the academic world. They work at a variety of media companies, such as daily newspapers, business press, and public television, as well as a media organization.

The academics participating in this study are all distinguished researchers within the field of media studies, but with different competencies such as media development, mobile media, and media economics, and from different universities in Sweden.

The scenario generating process was combined with semistructured interviews with media consumers in order to get more input on the media trends and possible future developments.

The media consumers participating in this study consisted of a mix of people living in small towns and bigger cities (such as Stockholm, Södertälje, Norrköping, Kalmar, Chicago and Urbana-Champaign) with a variety in ages, educational background, gender, interests and family situation. A total of nine consumer interviews were made in Sweden in October 2013 and January 2014, and seven consumer interviews were made in Illinois, USA, in February 2013. The aim with the interviews in the United States was to lift the perspective in order to get contrasting input to the interviews in Sweden.

Semi-structured interviews can be described as an interview situation where the interviewer leads the questioning, while at the same time the participant is given quite some freedom to elaborate on the subject and bring up other points relevant to the question, but without leaving the subject entirely [26]. The consumers participating in this study were asked to describe his or her media consumption habits five years ago, today, and what they expect them to be in the future. The Swedish consumers were also asked to comment on and discuss the four future scenarios in this study, which were presented to them.

The environmental parameters in this study were developed at two independent workshops with media and environmental experts. At that point the scenarios had already been finalized. The first environmental workshop was held in Sweden in November 2013, and consisted of one media studies expert, one future studies expert, two environmental experts working with life cycle assessments, and one environmental expert from the telecom industry.

The second environmental workshop was held in Finland in December 2013, and consisted of one media expert from the Finnish news industry, one media researcher, and four environmental experts with special focus on life cycle assessments of media products. At the environmental workshops, focus was entirely on the environmental aspects and parameters of the four scenarios, not on the actual scenarios. The main questions to the experts were:

1. Are you able to say anything about the environmental aspects of the four scenarios?

2. Can you agree on the most central parameters for environmental aspects of media consumption?

\section{RESULTS}

\section{Scenarios}

In the scenario generation process described above, a total of four future scenarios were created. The media scenarios presented in this study are further explored and discussed in an article by Picha Edwardsson and Pargman [27].

I have made the assumption that the amount of influence from the government in combination with the amount of commercial powers strongly affects the future of media, based on Hultén et al. [4], who discuss the duality between government regulations and the market. Thus, the scenario cross presented below is not orthogonal in regards to the parameters, but constructed around the four possible combinations of this duality.

\begin{tabular}{|l|l|c|}
\hline & $\begin{array}{c}\text { Strong governmental } \\
\text { control }\end{array}$ & $\begin{array}{c}\text { Weak } \\
\text { governmental } \\
\text { control }\end{array}$ \\
\hline Strong commercial powers & Scenario 2 & Scenario 3 \\
\hline Weak commercial powers & Scenario 1 & Scenario 4 \\
\hline
\end{tabular}

Fig. 1. The four scenarios, based on the four possible combinations in the scenario cross. 


\section{Environmental parameters}

As a result of previous research, literature studies and the environmental workshops in this study, the following list of environmental parameters (and parameterized technical and social trends with environmental features) was suggested:

- Number of electronic devices used in society, and type of devices.

- How often electronic devices are replaced on average.

- Environmental impact of energy use when using electronic devices. (Type of energy and energy efficiency.)

- Environmental impact of the production of electronic devices.

- Environmental impact of the waste of electronic devices. (Is there for example informal recycling, landfills or formal reutilization of the waste?)

- Amount of consumption in society in general.

- Environmental impact of network infrastructure, for example supporting ICT in society.

- Amount of travel among citizens.

- Amount of transportation of goods and services.

- Environmental impact of print products, full life-cycle.

- Amount of environmental information available, as well as the accuracy in the information and to what degree the consumers and other stakeholders have received the information.

Previous research supports the assumption of certain environmental parameters discussed at the workshops. For example Arushanyan et al. [28] conclude that in the case of online newspapers, manufacturing and operation of laptops, desktops and screens appears to be the key contributor to the environmental impacts.

Consequently, the number of electronic devices used in society, how often electronic devices are replaced on average, the amount of energy used when using electronic devices, environmental impact of the production of electronic devices, and environmental impact of the waste of electronic devices, consist an important part of the environmental parameters suggested in this study.

According to Arushanyan [10], user practices can affect the overall impact of many ICT solutions. In this study, I have considered parameters such as the amount of consumption in society in general, the amount of travel among citizens, and the amount of transportation of goods and services as important parameters indicating consumer behaviour.

At the workshop held in Finland in December 2013, the environmental impact of print products were discussed, as well as the environmental impact of network infrastructure, and the amount of environmental information available in society at large, which most likely makes a considerable difference when comparing the four scenarios in this study.

I will now present the scenarios of the future of media, developed in this study.
Scenario 1, "Strong governmental control, weak commercial powers"

The government is controlling or monitoring media content producers to an increasing degree, often referring this control to a way of defeating terrorism. Foreign companies are controlled by the government, which means that they have limited influence and limited possibilities to expand on the domestic media market. Public service is used for government propaganda, news shows are controlled by government authorities. Public service and printed newspapers receive governmental support to help them survive even though people are less interested in watching or reading them. Wikileaks supporters and other critical voices in society are controlled and limited by the government. Debates in social media and other types of forums are read and controlled by the government.

When discussing scenario 1, the participants in the environmental workshops assumed it to be rather beneficial in terms of environmental aspects. The government could possibly control much of the emissions. This is a positive thing, given that the government is interested in aiming for as low emissions as possible. The risk of this scenario, however, is that we could end up in a situation close to countries where the amount of environmental information is low, which means that the citizens are not aware of their environmental impact. The environmental impact of print products could either be high, if there are plenty of printed newspapers available, or low, if there for example only is one printed newspaper allowed by the government and printed books from abroad are limited. There is also a risk that the government is not working for the common good such as protecting the environment, but instead aims at protecting other interests in society such as the production of coal or defending polluting industries. Consequently, there is no guarantee that scenario 1 is especially favourable in terms of overall environmental aspects even though it might appear so at first.

\section{Scenario 2, "Strong governmental control, strong commercial powers"}

Press freedom is guaranteed by government control, which encourages free and independent media, but stops monopolies and cartels formed by foreign or national media companies. Media companies consolidate, which increases the amount of meetings so this means increased travel for the staff and more meetings with online tools. Smart phones become increasingly important in society for media use in general. Moving images/video is consumed on large or small platforms, independent of time and space. The lifecycle of new media devices becomes shorter, and the consumers have interest in new technology. The amount of e-waste increases every year. Energy prices increase in society. This leads to that the distribution of printed newspapers become more expensive, and that newspapers consider printing fewer copies per week and with less content (fewer pages). The distribution of morning papers go down/go through radical changes. The increased energy price also leads to the introduction of new 
technical devices with low energy use and overall low environmental impact become increasingly important in society.

The conclusion from discussing scenario 2 is that it is mixed in terms of environmental aspects. On the one hand, the production, consumption and waste handling of the electronic devices have become smarter and more environmentally conscious. On the other hand, the total amount of consumption in society increases to a great deal, which is affecting the environment in a negative way. Consequently, this scenario is beneficial for the environment in some respects, but there are also negative aspects.

\section{Scenario 3, "Weak governmental control, strong commercial powers"}

The government has very little, or no, control over media, media content and the organization of media companies. Most of the news media content, of social forums and of societal information is available on the web. The largest sites are run by citizen journalists, or get their content from crowdsourcing of information, and they exist side by side with large multinational media companies. Public service is shut down, and so are the TV license fee and other media taxes. Multinational media conglomerates dominate the Nordic media market. They own the majority of the Nordic sites and do not have journalism as their guiding star, but mainly economic interests. Foreign companies strive to have monopoly on the Nordic market. Media content broadcast (in TV and radio), and published on the web, becomes to an increasing extent focused on entertainment. Very little documentary or informational material is broadcast. Focus is mainly on entertainment. The general knowledge level in society decreases. The social gaps increase. Moving images, or video, is becoming increasingly important and more frequent in relation to text based media content. The consumers' attention span gets shorter - they have little patience with consuming complex media content. The digital market for advertising is dominated by large companies. The media market is increasingly agile.

The conclusion from discussing scenario 3 is that it is quite negative in terms of environmental aspects. The focus on entertainment in media means that little environmental information is published or broadcasted. Consumption in society is high in general. People live in their bubbles and have little interest in "larger" questions such as sustainability. The producers of the electronic devices are not particularly interested in making environmentally friendly goods and services. The government, who could give incentives to companies to work in a more sustainable way, is quite weak and therefore lacks the influence. In general, this is quite a negative scenario when considering the environmental aspects.
Scenario 4, "Weak governmental control, weak commercial powers"

In this scenario, news updates with large amounts of usergenerated content is mainly found online. Most of traditional media content as well as social forums and societal information is found without restrictions and free of charge online. The largest web sites are run by citizen journalists. Crowdsourcing is an important source for information. Multinational companies have played out their role in society at large. The government has very little influence over the media market. Bloggers and smaller media players dominate, or work together in network structures. Web sites where consumers sell and buy goods and services from each other dominate the net trade. People like to share resources, often by using social media channels to communicate.

The conclusion from discussing scenario 4 is that it is quite beneficial in terms of environmental aspects. This network society means less consumption in general. On the other hand, there might be a quite high environmental impact from the production and waste handling of electronic devices per device, due to the small amount that is produced. The amount of environmental information available in this scenario could either be high - if people are interested in the subject and publish a lot of information - or low, if this is not the case.

\section{Consumer input}

In order to get a broader perspective of the scenarios in this study, as well as an indication of the environmental awareness among media consumers in general, I interviewed 16 media consumers in Sweden and the United States, as described above. The result of the interviews shows that very few consumers connect media consumption with environmental concerns, except when they bring their printed newspapers to the recycling. The interviewees in the United States, however, claimed that they usually did not recycle newspapers. My general impression from the interviews is that the American media consumers were not aware of the connection between media consumption and environmental aspects at all.

On a general level, the majority of the interviewed persons considered printed media as more environmentally damaging compared to electronic media, which was considered "clean". ICT and the transformation of the ICT society as a whole was mostly considered as something favourable for the environment, except when we started to discuss energy-related issues and the interviewed persons started to reflect more over the system around media production and media consumption in relation to the ICT society. At that point, many of the interviewees changed their opinions and their interest and awareness seemed to increase to some degree.

Furthermore, the interviews made in this study supported the observation made by Teljas et al. [29] that media consumption differs considerably among people. It is very rare to find one person who has the exact same media habits as another person. Media consumption in general depends on the consumers' age, where they live, what their household looks like, what personal interests they have, how educated they are, 
and finally how much money they have at their disposal [29]. Another important aspect is the consumers' available time, according to the interviews made in this study.

When confronted with the four future scenarios described above, the Swedish consumers in general seemed very interested and amused. A majority found that scenario 2 and possibly 3 were the most likely to happen. However, few could imagine a future as described in scenario 1, and most of them thought that scenario 4 was more of a fantasy. At the same time, they thought that some, often contradictory, aspects in each scenario could potentially happen in the near future.

\section{ANALYSIS AND DISCUSSION}

The four future scenarios described above would potentially have different consequences for the environment, in such a way that some scenarios are more environmentally sustainable than others. Below is a brief overview, based on the results from the workshops in this study.

\begin{tabular}{|c|c|c|c|c|}
\hline $\begin{array}{c}\text { Environmental } \\
\text { parameters }\end{array}$ & Scen 1 & Scen 2 & Scen 3 & Scen 4 \\
\hline $\begin{array}{l}\text { Number of electronic devices } \\
\text { used in society }\end{array}$ & FEW & MANY & MANY & FEW \\
\hline $\begin{array}{l}\text { How often electronic devices } \\
\text { are replaced on average }\end{array}$ & SELDOM & OFTEN & OFTEN & SELDOM \\
\hline $\begin{array}{l}\text { Environmental impact of } \\
\text { energy use when using } \\
\text { electronic devices }\end{array}$ & HIGH & HIGH & HIGH & LOW \\
\hline $\begin{array}{l}\text { Environmental impact of the } \\
\text { production of electronic } \\
\text { devices }\end{array}$ & LOW & HIGH & HIGH & LOW \\
\hline $\begin{array}{l}\text { Environmental impact of the } \\
\text { waste of electronic devices }\end{array}$ & LOW & HIGH & $\mathrm{HIGH}$ & LOW \\
\hline $\begin{array}{l}\text { Amount of consumption in } \\
\text { society in general }\end{array}$ & LOW & HIGH & HIGH & LOW \\
\hline $\begin{array}{l}\text { Environmental impact of } \\
\text { network infrastructure }\end{array}$ & LOW & HIGH & HIGH & HIGH \\
\hline $\begin{array}{l}\text { Amount of travel among } \\
\text { citizens }\end{array}$ & LOW & HIGH & HIGH & LOW \\
\hline $\begin{array}{l}\text { Amount of transportation of } \\
\text { goods and services }\end{array}$ & LOW & $\mathrm{HIGH}$ & $\mathrm{HIGH}$ & LOW \\
\hline $\begin{array}{l}\text { Environmental impact of } \\
\text { print products, full life-cycle }\end{array}$ & $\begin{array}{l}\text { LOW/ } \\
\text { HIGH }\end{array}$ & LOW & LOW & LOW \\
\hline $\begin{array}{l}\text { Amount of environmental } \\
\text { information available }\end{array}$ & LOW & HIGH & LOW & $\begin{array}{l}\text { HIGH/ } \\
\text { LOW }\end{array}$ \\
\hline
\end{tabular}

Fig. 2. The environmental parameters in relation to the four scenarios.

As shown above, the workshop participants considered scenarios 1 and 4 to have in general less overall environmental impact than scenarios 2 and 3 . One of the reasons is that the number of electronic devices used in society is smaller in scenarios 1 and 4 than in the other scenarios.
Perhaps the amount of energy used when using electronic devices might be lower in the future, thanks to better equipment. However, in scenarios 2 and 3, it is assumed that there will be so many devices that the overall impact still will be higher than in scenarios 1 and 4 . The same might be true for the environmental impact of the production of electronic devices.

The environmental impact of the waste of electronic devices follows the pattern of the production and use. The more devices used in society, the more waste is created. However, it is also important to consider if the waste treatment is done in an appropriate way or not. In scenarios 1 and 4, it is assumed that people to an increasing degree will share and trade devices with each other. In the other scenarios, there is more of a consumption mentality, where we update our equipment often and discard our old equipment.

The workshop participants assumed that the amount of travel is higher in scenarios 2 and 3 than in the other scenarios, which creates a higher environmental impact. The amount of transportation of goods and services is also assumed to be high in scenarios 2 and 3, which means a high environmental impact. When it comes to the environmental impacts of print products, the workshop participants assumed that this will be quite low in all four future scenarios, except in scenario 1 . This is due to the fact that the amount of print products is expected to decrease in society, due to the increase of digital equivalents used for consuming media content.

The workshop participants considered the amount of environmental information to be low in scenario 1 (due to too much governmental control), in scenario 3 (due to too little governmental control) and possibly in scenario 4 (depending on the citizens' interest in environmental information). They further assumed that there would be a high amount of environmental information in scenario 2, where the governmental control matches the commercial powers.

There are limitations in the analysis above, due to the fact that it is based on results from two workshop discussions, with a limited amount of experts.

I would argue that there are many potentials and opportunities for change for the future ICT society. A central action is to make consumers aware of their environmental impact, and encourage them to use their electronic equipment with care. It is also important to encourage the development of energy efficient equipment as well as to take care of the resources in the form of electronic waste in a sensible way. In this process to increase knowledge and awareness among consumers and business developers, I would argue that using different media channels could prove to be very efficient. According to Eide and Kunelius, it is crucial that media and journalism invent and test new routines for communication when facing a global challenge such as climate change/global warming [30, p.17]. The more accurate the available information is, the higher is the chance that consumers and other stakeholders such as business developers become aware of their environmental impact and their possibilities to minimize it. 


\section{CONCLUSIONS}

In this study, I have tried to answer the following questions: What could be the characteristics of media consumption in different future scenarios? What parameters are central in future scenarios around media consumption, seen from an environmental perspective? How will changes in these parameters affect the environmental aspects of media consumption?

My conclusions of the characteristics of the media consumption are presented in each of the four scenarios described above. I have assumed that the amount of influence from the government in combination with the amount of commercial powers strongly affects the future of media, based on Hultén et al. [4], who discuss the duality between government regulations and the market.

Based on the four scenarios described above, I have defined eleven parameters which are considered central when exploring media consumption from an environmental perspective.

The environmental experts participating in this study consider the most central parameters around media consumption to be connected to electronic devices, travel, transportation, energy use and waste. The environmental aspects of these parameters depend not only on the total amount of devices, travel, transportation, energy and waste, but also on the way the devices are produced and used, how travel and transportation are done, what kind of energy is used, and how the waste is treated. This means that even if the number of the parameters mentioned above is high, the environmental impact could be low if for example the production is energy efficient and has a comparatively low environmental impact, if only renewable energy is used, and if the devices are recycled in an appropriate way, et cetera.

In order to answer how changes in these parameters will affect the environmental aspects of media consumption, I conclude that there are many opportunities for change, such as making consumers aware of their environmental impact, and encourage them to use their electronic equipment with care. Perhaps one of the main findings is that the interviews made in this study showed that most consumers are not aware of the connection between media consumption and environmental aspects.

Regarding the possible future of media and the ICT society, we might see a little of all four scenarios described above. Most likely there will be many different futures existing side by side, all depending on who you are (including your age, where you live, what your household looks like, what personal interests you have, how educated you are, and how much time and money you have at your disposal). The environmental aspects of these different futures depend on each person's life situation and a number of choices that each consumer makes concerning environmental issues, in combination with the societal structure at large.

\section{ACKNOWLEDGEMENTS}

I would like to thank all experts and consumers participating in this study. I would also like to thank my supervisors Johan Stenberg, Nils Enlund and Åsa Moberg, and my colleagues at the Department for Media Technology and Interaction Design and at the Centre for Sustainable Communications at KTH Royal Institute of Technology in Stockholm, Sweden. Special thanks go to Yevgeniya Arushanyan for especially valuable input. I would also like to thank Hanna Pihkola, Minna Nors, Maija Federley and Katri Behm at VTT in Finland, for your encouraging words and valuable input.

\section{REFERENCES}

[1] Nygren, G., and Wadbring, I. Ed. (2013) På väg mot medievärlden 2020. Journalistik, teknik, marknad. Lund, Studentlitteratur.

[2] Sundin, S. (2013) Den svenska mediemarknaden 2013. Medienotiser $\mathrm{nr}$ 3. Nordicom-Sverige, Göteborg: Göteborgs universitet.

[3] Kaye, J. and Quinn, S. (2010) Funding journalism in the digital age. Business models, strategies, issues and trends. Peter Lang Publishing, New York.

[4] Hultén, O., Tjernström, S., Melesko., S. Ed. (2010) Media mergers and the defence of pluralism. Nordicom, Göteborg.

[5] Bradley, G. (2010) The convergence theory on ICT, society and human beings - towards the good ICT society. Triple C Journal for a global sustainable information society, vol 8, no 2, pp 183-192.

[6] Górniak-Kocikowska, K. (2007) From computer ethics to the ethics of global ICT society. Journal of Library Hi Tech, vol 25, no 1, pp 47-57.

[7] Kosow, H. and Gassner, R. (2008) Methods of Future and Scenario Analysis. Overview, Assessment and Selection Criteria. German Development Institute, DIE.

[8] Fuchs, C. (2011) Foundations of Critical Media and Information Studies. London: Routledge Advances in Sociology.

[9] Åkesson, M. (2009) Digital Innovation in the Value Networks of Newspapers. Gothenburg Studies in Informatics, Report 42, September 2009.

[10] Arushanyan, Y. (2013) LCA of ICT solutions - Environmental impacts and challenges of assessment. Licentiate thesis in Planning and Decision Analysis at KTH Royal Institute of Technology, Stockholm, Sweden.

[11] Crosbie, T. (2008) Household energy consumption and consumer electronics: The case of television. Journal of Energy Policy no 36, pp 2191-2199.

[12] Kronqvist, M., Löfgren, C., Sturges, M. and Teleman, A. (2010) Miljöbedömning av mediekanalerna papperstidskrift och Internetpublicering. Innventiarapport nr 97. Stockholm: Innventia.

[13] Moberg, Å., Johansson, M., Finnveden, G. and Jonsson, A., (2010) Printed and tablet epaper newspaper from an environmental perspective - A screening lifecycle assessment. Environmental Impact Asessment Review, 30(2010), pp. 177-191.

[14] Moberg, Å., Borggren, C. and Finnveden, G. (2011) Books from an environmental perspective - Part 2: e-books as an alternative to paper books, International Journal of Life Cycle Assessment, 16, pp. 238-246.

[15] Picha Edwardsson, M. (2012) Media processes for content production. Studies of structures and climate impacts. Licentiate thesis in Media Technology, KTH Royal Institute of Technology, Stockholm, Sweden.

[16] Reichart, I., Hischier, R. (2003) The Environmental Impact of Getting the News A Comparison of On-Line, Television, and 
Newspaper Information Delivery. Journal of Industrial Ecology, Vol. 6, No. 3-4, pp 185-200.

[17] Toffel, M. W. and Horvath, A. (2004) Environmental Implications of Wireless Technologies: News Delivery and Business Meetings. Environmental Science and Technology VOL. 38, NO. 11

[18] Arushanyan, Y. and Moberg, Å. (2012) What makes a difference for environmental performance of online newspapers? In: KlausDieter Lang, Nils F. Nissen, Andreas Middendorf, Perrine Chancerel (ed) Electronics goes green 2012+ - Joint International Conference and Exhibition, Proceedings. Berlin, Germany, September 2012.

[19] Schien, D., Shabajee, P., Yearworth, M., Priest, C.W. (2013) Modeling and assessing variability in Use Phase Energy of online multimedia services. http://research-

information.bristol.ac.uk/files/9892341/jie_paper_prepress.pdf

[20] Yearworth, M., Schien, D., Preist, C., Shabajee, P. (2011) Systems Modelling of New Media Services. http://www.systemdynamics.org/conferences/2011/proceed/papers/P1 040.pdf

[21] Rademaker, C. A. (2013) Green media: Exploring green media selection and its impact on communication effectiveness. Doctoral thesis in Business administration at Stockholm School of Economics.

[22] Jenkins, H. (2006) Convergence Culture - Where old and new media collide. New York: New York University Press.
[23] Svenfelt, Å., Höjer, M. (2012) Framtidsstudier och osäkerheter, in: Alm, S., Palme, J., Westholm, E. (Ed.), Att utforska framtiden: valda perspektiv (pp. 1-255). Stockholm: Dialogos Förlag.

[24] Börjeson, L., Höjer, M., Dreborg, K-H., Ekvall, T. and Finnveden, G. (2006) Scenario types and techniques: Towards a user's guide. Futures 38 (7) pp. 723-739.

[25] van der Heijden, K. (1996) Scenarios: The Art of Strategic Conversation. John Wiley and Sons, London.

[26] Bryman, A. and Bell, E. (2007) Business research methods. New York: Oxford University Press.

[27] Picha Edwardsson, M., and Pargman, D. (2014) Explorative scenarios of emerging media trends. To be submitted.

[28] Arushanyan, Y., Ekener-Petersen, E., and Finnveden, G. (2013) Lessons learned - Review of LCAs for ICT products and services. Computer Industry, http://dx.doi.org/10.1016/j.compind.2013.10.003

[29] Teljas, C., Jonsson, A. and Enlund, N. in Hvitfelt, H. and Nygren, G. (2009) På väg mot medievärlden 2020, journalistik, teknik, marknad. Lund: Studentlitteratur.

[30] Eide, E. and Kunelius, R. (2012) Media meets climate. The global challenge of journalism. Nordicom, Göteborg. 